\title{
Sound, music, and magic in football stadiums - ERRATUM
}

\author{
PEDRO SILVA MARRA and FELIPE TROTTA \\ doi:10.1017/S0261143018000727, published by Cambridge University Press, 3 January \\ 2019
}

This paper was published with an incorrect author name in the reference section. The correct reference follows:

Back, L. 2003. 'Sounds in the crowd', in The Auditory Culture Reader, ed. M. Bull and L. Back (New York, Berg).

The author apologises for the error and any inconvenience caused.

\section{Reference}

Marra, P., \& Trotta, F. 2019. Sound, music and magic in football stadiums. Popular Music, 38(1), 73-89. 